\title{
ACRL candidates for 1992 elections
}

Be sure to vote in the elections this spring.

$\mathrm{T}$ he listing for each of the candidates includes their title, institution, and institutional address.

\section{Vice-President/President-Elect}

Thomas Kirk, College Librarian and Professor of Library Science, Hutchins Library, Berea College, Berea, KY 40403; Barbara J. Wittkopf, Reference Librarian, Reference Services, Middleton Library, The LSU Libraries, Baton Rouge, LA 70803.

\section{Afro-American Studies Librarian Section (AFAS)}

Vice-Chair/Chair-Elect: William C. Welburn, Diversity/Special Services Librarian, University of Iowa Libraries, Iowa City, IA 52246; Robert Miller, Curator, Harsh Research Collection, Carter G. Woodson Regional Library, Chicago Public Library, $9525 \mathrm{~S}$. Halsted Street, Chicago, IL 60628.

Secretary: Diana L. Brice, Head Social Sciences, Woodson Regional Library, Chicago Public Library, 9525 S. Halsted Street, Chicago, IL 60628; Joyce E. Jelks, Manager, Acquisitions Department, Atlanta-Fulton Public Library, 1 Margaret Mitchell Square NW, Atlanta, GA 30303-1089.

Member-at-Large: (elect two) Carol A Rudisell, Associate Librarian, Reference Department, University of Delaware Library, Newark, DE 197175267; Michael C. Walker, Reference Librarian, Virginia Commonwealth University, Cabell Library, 901 Park Avenue, Box 2033, Richmond, VA 232842033; Rochelle R. Ballard, Reference Librarian, University of Central Florida Libraries, P.O. Box 25000, Orlando, FL 32816-0666.

\section{Anthropology and Sociology Section (ANSS)}

Vice-Chair/Chair-Elect: Kathryn L. Creely, Melanesian Studies and Anthropology Librarian,
University of California-San Diego, La Jolla, CA 92093-0175.

Member-at-Large: J. Christina Smith, Anthropology/Sociology Bibliographer, Boston University, Mugar Memorial Library, 771 Commonwealth Avenue, Boston, MA 02215; Mary M. Koenig, Library Coordinator Title VI International Studies Grant, University of Minnesota, 5 Wilson Library, 309 19th Avenue South, Minneapolis, MN 55455.

\section{Arts Section (ARTS)}

Vice-Chair/Chair-Elect: Sandra T. Mooney, Head, Design Resource Center, Louisiana State University Libraries, Baton Rouge, LA 70803; Madeleine M. Nichols, Curator, Dance Collection, New York Public Library for the Performing Arts, 455 Fifth Avenue, New York, NY 10016.

\section{Asian and African Section (AAS)}

Vice-Chair/Chair-Elect: Katharine Elsasser, Subject Cataloger, Library of Congress, Washing ton, DC 20541.

Member-at-Large: Donald Clay Johnson, Librarian, University of Minnesota, Minneapolis, MN 55455; Brenda E. Bickett, Arabic Materials Specialist, Georgetown University, Washington, DC 20013-7445.

\section{Bibliographic Instruction Section (BIS)}

Vice-Chair/Chair-Elect: Lori L. Arp, Head, Central Reference, University of Colorado at Boulder, Campus Box 184, Boulder, CO 80309; Barbara A. MacAdam, Head, Undergraduate Library, University of Michigan, Ann Arbor, MI 48109.

Secretary: Craig A. Mulder, Program Director for Instruction and Curriculum Support, Welch Medical Library, The Johns Hopkins University, 1900 E. Monument Street, Baltimore, MD 21205; Beth S. Woodard, Central Information Ser- 
vices Librarian and Associate Professor of $\mathrm{Li}^{-}$ brary Administration, Reference Library, University of Illinois, 1408 W. Gregory Drive, Urbana, IL 61801.

Member-at-Large: Mary J. Petrowski, Assistant Undergraduate Librarian, Undergraduate Library, University of Illinois, 1402 West Gregory Drive, Urbana, IL 6180I; Margaret R. Wells, Head of Bibliographic Instruction, Undergraduate Library, SUNY at Buffalo, Capen Hall, Buffalo, NY 14260.

\section{College Libraries Section (CLS)}

Vice-Chair/Chair-Elect: Barbara J. Brown, University Librarian, Washington and Lee University, University Library, Lexington, VA 24450; Rebecca A. Wilson, Assistant Director/Systems Coor dinator, Susquehanna University, Blough-Weis Library, Selinsgrove, PA 17870

Secretary: Michael J. LaCroix, Director of Library Services, F.W. Gingrich Library, Albright College, Reading, PA 19604-5234; I eRoy S. Strohl III, Library Director, Mary Washington College Library, Fredericksburg, PA 22401-5358.

Member-at-Large: Allison L. Gould, Associate Systems Librarian and Head of Circulation, Oberlin College Library, Oberlin, OH 44074; Pamela Snelson, Assistant Director for Automation and Public Services, Drew University Library, Madison, NJ 07940

\section{Community and Junior College Libraries Section (CJCLS)}

Vice-Chair/Chair-Elect: Lenora C. Lockett, Library Director, Delgado Community College, Moss Memorial Library, 615 City Park Avenue, New Orleans, LA 70119; Margaret A. "Peggy" Holleman, Director of Library Services, Pima Community College-West Campus LRC, 2202 W. Anklam Road, Tucson, AZ 85709.

Secretary: Susan M. Anderson, Director of Libraries, St. Petersburg Junior College, Campus Library, 6605 Fifth Avenue, P.O. Box 13489, St. Petersburg, FL 33733; Cary L. Sowell, Head Librarian, Austin Community College, Northridge Campus LRC, Austim, TX 78714.

\section{Education and Behavioral Science Section (EBSS)}

To be announced.

\section{Extended Campus Library Services Section (ECLSS)}

Vice-Chair/Chair-Elect: Thomas E. Abbott,
Director of Learning Resources and Equal Opportunity, University of Maine at Augusta, University Drive, Augusta, ME 04330 and the Community College of Maine; Lynn B. LaBrake, Associate Director of Libraries, University of Central Florida, University Libraries, P.O. Box 25000, Orlando, FL 32816-0666.

Member-at-Large: Virginia S. Randolph, Visit ing Professor in Humanities/Librarian, Pepperdine University Libraries, Payson Library, 24255 Pacific Coast Highway, Malibu, CA 90263; Carol M. MouIden, Public Services Librarian/Coordinator of Off-Campus Library Services, National-Louis University, University Library, 2840 Sheridan Road, Evanston, IL 60201.

\section{Law and Political Science Section (LPSS)}

Vice-Chair/Chair-Elect: Charles D. Spornick, Collection Management Coordinator, Emory University, General Libraries, Robert W. Woodruff Library, Atlanta, GA 30322;

Member-at-Large: Catherine F. Doyle, Access Services Librarian, Christopher Newport College, Captain John Smith Library, 50 Shoe Lane, Newport News, VA 23606.

\section{Rare Books and Manuscripts Section (RBMS)}

Vice-Chair/Chair-Elect: Jackie M. Dooley, Special Collections Librarian, University of California, San-Diego, La Jolla, CA 92093-0175; Jennifer B. I,ee, Curator of Printed Books, The John Hay Library, Brown University, Box A, Providence, RI 02912.

Member-at-Large: Charles McNamara, Curator of Rare Books, University of North Carolina, Wilson Library, Special Collections, Chapel Hill, NC 27514; Barbara Paulson, Program Officer, Division of Preservation and Access, National Endowment for the Humanities, Room 802, 1100 Pennsylvania Avenue, Washington, DC 20506.

\section{Science and Technology Section (STS)}

Vice-Chair/Chair-Elect: Janet S. Fore, Reference Librarian and Assistant Head, Science-Engineering I ibrary, University of Arizona, Tucson, AZ 85721; Helen E. Gbala, User Services Librarian, NOTIS Systems, Inc., Evanston, IL 60201-3622.

Secretary: Barbara J. DeFelice, Reference Li brarian, Dartmouth College, Kresge Physical Sciences Library, Hanover, NH 03755; Janet Chisman Reference Librarian and Database Search Coordinator, Owen Science \& Engineering Library, Washington State University, Pullman, WA 99164-3200. 


\section{Slavic and Eastern European Section (SEES)}

Vice-Chair/Chair-Eleet: Leena Siegelbaum, Germanic/Slavic Bibliographer, Michigan State University Libraries, East Lansing, MI 48824-1048.

Member-at-Large: Tatiana Goerner, Slavic Cataloger, Stanford University Libraries, Stanford, CA 94305-6004; Ruth Wallach, Reference/Slavic Biblingrapher, University of Southem California, Doheny Reference Center, Los Angeles, CA 90089

\section{University Libraries Section (ULS)}

Vice-Chair/Chair-Elect: Noreen S. Alldredge, Dean of Libraries, Montana State University, Bozeman, MT 59717; John W. Collins III, Librarian, Gutman Library, Harvard Graduate School of Education, 6 Appian Way, Cambridge, MA 02138.

Member-at-Large: Sarah E. How, Cornell University Library, Ithaca, NY 14853-5301; Kent H. Hendrickson, Dean of Libraries, University of Nebraska-Lincoln, 106 I ove I ibrary, Iincoln, NE 68588-0410;

Member-at-Large: Hiram L. Davis, Director of Libraries, Michigan State University, East Lansing, MI 48824-1048; Beverlee A. French, Assistant University Librarian-Sciences, University of California-Davis, Shields Library, Davis, CA 95616.

\section{Western European Specialists Section (WESS)}

Vice-Chair/Chair-Elect: Richard Hacken, E11ropean Studies Bibliographer, Brigham Young University, Provo, UT 84602; James H. Spohrer, Librarian for the Germanic Collections, University of California-Berkeley, 390 Doe Library, Berkeley, CA 94720 .

Secretary: Thomas M. Izbicki, Resource Services Librarian for European and Byzantine History and Philosophy, Milton S. Eisenhower Library, Johns Hopkins University, Baltimore, MD 21218; Charles G. Spetland, Reference Librarian/Bibliographer, University of Minnesota, Minneapolis, MN 55455 .

Member-at-Large: Craig Likness, Humanities Librarian/Head Bibliographer, Trinity University, San Antonio, TX 12033; Catharine M. E. Halls, Librarian 11, New York Public Library, Room 315, 42nd Street and Fifth Avenue, New York, NY 10018.

\section{Women's Studies Section (WSS)}

Vice-Chair/Chair-Elect: BettyJ. Glass, Instructional Services Librarian, University of Nevada-
Reno, Main Library/322, Reno, NV 89557-0044; Pauline D. Manaka, Social Sciences Librarian, University of California, General Library, Irvine, CA 92713 .

Secretary: Nancy M. Stanley, Head, Acquisitions Receiving, Penn State University Libraries, E506 Pattee Iibrary, University Park, PA 16802; Kristine J. Anderson, Bibliographer and Reference Librarian, Purdue University, HSSE Library, Stewart Center, West Lafayette, IN 47906.

Member-at-Large: Mila C. Su, Senior Assistant Librarian-Reference, Robert E. Eiche Library, Penn State Altoona Campus, Ivyside Park, Altoona, PA 16601-3760; Rita M. Pellen, Assistant Director for Public Services, Florida Atlantic University, S.E. Wimberly Library, P.O. Box 3092 , Boca Raton, FL 3343I.

\section{Letters}

(C\&RL News welcomes your signed, typed comment on recent content in our pages or on matters of general interest to the academic or research library profession. Letters beyond 250 words will not be acceptedormaybe edited to fit space. Letters should be addressed to: The Editor, C\&RL News, $50 \mathrm{E}$. Huron Street, Chicago, IL 60611; fax: (312) 2807663.)

\section{War is not exciting}

To the Editor:

I am writing to express my disgust and outrage over a notice on page 656 of the November issue of the magazine, regarding "War in the Gulf."

"Recapitulates the exciting drama"???????? My god. Where are your minds?

There were 100,000 Iraqi men killed in that war. A recent U.N. report states that large numbers of Iraqi children are still dying from malnutrition and fouled drinking water due to American bombing, and Kuwaiti civilians were killed on the road to Basra by American bombs.

In the past I have had an article published in C \&RL News. In February, when my membership is due, I will not be renewing my subscription/membership.

I would further castigate the ALA for abandoning its principles on intellectual freedom. ALA defends banal pornography it didn't have the courage to speak out against government censorship before, during, and after the Gulf War.-Kate Bradley, Bellevue Community College, Bellevue, Washington 